\section{Original Research}

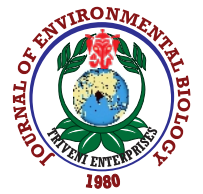

DOI : http://doi.org/10.22438/jeb/42/4(SI)/MRN-1584a

Journal website : www.jeb.co.in $\star$ E-mail : editor@jeb.co.in

Journal of Environmental Biology

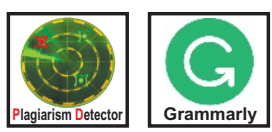

\title{
Influence of enzymes and extraction conditions on high yield of cottonseed milk
}

\author{
S. Thirukkumar*, G. Hemalatha', S. Vellaikumar ${ }^{1}$, M. Murugan ${ }^{3}$ and S. Amutha ${ }^{1}$ \\ ${ }^{1}$ Department of Food Science and Nutrition, Community Science College and Research Institute, Tamil NaduAgricultural University, Madurai-625104, India \\ ${ }^{2}$ Department of Biotechnology, Agricultural College and Research Institute, Tamil Nadu Agricultural University, Madurai-625 104, India \\ ${ }^{3}$ Department of Agricultural Entomology, Tamil Nadu Agricultural University, Coimbatore-641 003, India
}

*Corresponding Author Email : psthirukumar@gmail.com

\section{Abstract}

Aim: This research aimed to optimize suitable hydrolytic enzymes for maximizing cottonseed milk extracts for high cottonseed milk yield, protein content and low gossypol level.

Methodology: Known amount of cottonseed was soaked for 90 min at $32^{\circ} \mathrm{C}$ and blended (cottonseed:water@1:6). Different aliquots of the blended cottonseed slurry were treated with $1 \%$ of enzymes viz., protease, cellulase and aamylase enzyme at $\mathrm{pH} 7.0$ followed by incubation at 40 and $52^{\circ} \mathrm{C}$ for $2.30 \mathrm{hr}$ for the extraction of cottonseed milk. The enzyme activity of extracted milk was subsequently inactivated by pasteurization $\left(90^{\circ} \mathrm{C}, 5 \mathrm{~min}\right)$. Further analysis of physicochemical characteristics was also carried. The control sample included milk extraction from non-enzyme treated cottonseed milk extract $\left(30 \pm 2^{\circ} \mathrm{C}\right)$.

Results: Among different treatments, cottonseed milk extraction using protease enzyme at $40^{\circ} \mathrm{C}$ incubation showed the highest milk yield $(86.71 \%)$ with the lowest sedimentation (3.72\%). Further incubation

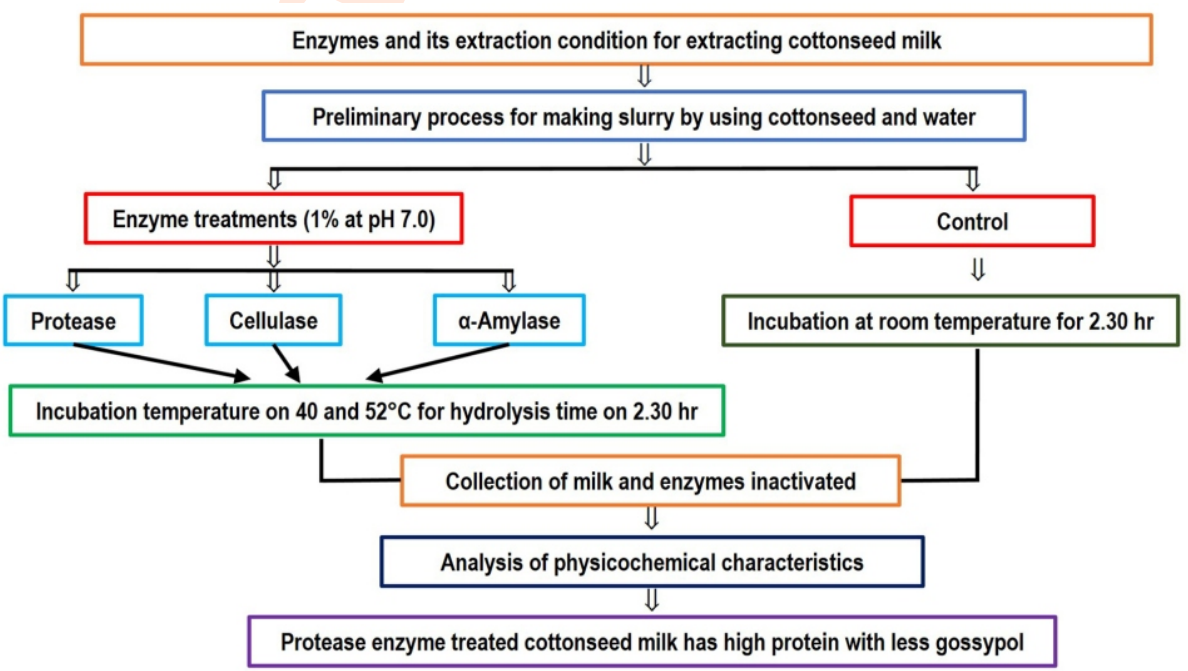
$40^{\circ} \mathrm{C}$ and $52^{\circ} \mathrm{C}$ showed the highest protein

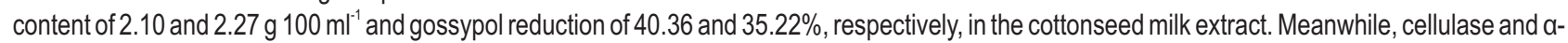
amylase enzymes treated samples at both incubation temperatures showed poor physico-chemical characteristics as compared to control.

Interpretation: Protease enzyme seems to be the most suitable for optimum or higher extraction of cottonseed milk.

Key words: Cottonseed milk, Enzymes, Gossypol, Protein

How to cite : Thirukkumar, S., G. Hemalatha, S. Vellaikumar, M. Murugan and S. Amutha: Influence of enzymes and extraction conditions on high yield of cottonseed milk. J. Environ. Biol., 42, 1195-1200 (2021). 


\section{Introduction}

Lactose intolerance is a digestive disorder caused due to the inability to digest lactose in mammalian milk. The digestive enzyme lactase is important for the breakdown of lactose into glucose and galactose. Insufficient production of lactase and/or $\beta$-galactosidase at the brush border of human intestine leads to undigested lactose, which moves to the gut system causing gastrointestinal symptoms such as bloating, diarrhea and abdominal pain (Jasielska and Grzybowska-Chlebowczyk, 2019). Consumption of non-dairy food products or avoidance of dairy products is the primary solution for lactose intolerance. As a result of increasing world population, cultural changes, food consumption patterns, veganism and modernization of food and beverage industry, there is immense scope for introduction of lactose free dairy products for the lactose intolerant (Sethi et al., 2016). Hence, plant based milk products are a great alternative for dairy products which also possess the added advantage attributed to inherent functional and nutraceutical components such as fibers, vitamins, minerals and antioxidants for promoting health (Das et al., 2012). Due to increasing demand for non-dairy based food products and growing health concerns, various plant sources are used as alternative for non-dairy milk product.

Suitable plants as non-dairy milk sources include legumes, nuts, seeds, pseudocereals, cereals etc. (Sethi et al., 2016). Among the plant sources, cottonseed is one of the potential source for meeting the requirement properties of milk emulsion with improved nutritional status, but has not been exploited as a source of human nutrition. Cottonseed is a good source of energy, crude protein, fiber content and fat. Also its byproducts have a high biological value and safe fatty acid profile such as $50 \%$ monounsaturated fatty acid, $21 \%$ polyunsaturated fatty acid and $29 \%$ saturated fatty acid which conforms to human health guidelines (Bertrand et al., 2005; Prasad and Blaise, 2020). However, cottonseeds contain toxic compounds such as gossypol, with concentration ranging from 0.02 to $6.64 \%$ in seeds among various cotton varieties. The presence of a high amount of gossypol decreases the bioavailability of lysine, arginine and cysteine (Gadelha et al., 2014). Gossypol binds with iron to form gossypoliron complex, which can affect erythropoiesis and also increase erythrocyte fragility, associated with anemia (Tang et al., 2017). Gossypol associated toxicity issues have been reported in monogastric animals ranging from various degrees of health issues such as loss of appetite, edema of lungs, impaired body weight gain, listlessness and stunted growth.

Studies have shown that gossypol is toxic to monogastric animals, which results in ascites and hepatocyte degeneration in liver, decreased sperm count, spermatogenesis and impaired immunocompetence through reduced number of leukocyte and primarily lymphocytes (Santana et al., 2015; Wang et al., 2019; Zhang et al., 2020). In addition to gossypol toxicity effects, cottonseed has several important phytochemical components of current interest due to the presence of several biological properties, which are used for treatment of leukemia, colon carcinoma, breast cancer, prostate cancer and other malignancies (Xiong et al., 2017; Cao et al., 2018; Yu etal., 2020). The maximum permissible consumption level of gossypol as regulated by the United State Food and Drug Administration (USFDA) is $450 \mathrm{mg} \mathrm{kg}^{-1}$ and by the Food and Agricultural Organization/World Health Organization (FAO/WHO) as 600 $\mathrm{mg} \mathrm{kg}^{-1}$ in cotton seed-based food products for human consumption (Prasad and Blaise, 2020). Normally, plant milks are prepared by crushing the plant material with water followed by extraction of water soluble components.

Extraction of beneficial nutrients such as lipids, flavonoids and alkaloids with water soluble protein components is a complex mechanism, which depends on the chemistry of inner and outer part of cell-matrix, particularly the presence of dietary fiber and other insoluble components of plant material (Sethi et al., 2016). Hydrolytic enzymes such as cellulase, hemicellulase, amylase, lipase and protease, in addition play a major role in extracting these components by cellular fragmentation and destruction, also increases the yield of extracted compounds by modifying the chemical characteristics with improved efficacy (Kirk etal., 2002).

Overall, few studies have been conducted on the extraction of plant-based milk by using enzymes and their interaction in various seeds with the exception of cottonseed. In view of the above, this study aimed to evaluate different hydrolytic enzymes for extraction of cottonseed milk at different temperature for high cottonseed milk yield, high protein content and low gossypol levels, which would provide leverage exploiting of cottonseed as plant based milk for safe source of nutrition and an alternative for animal source milk.

\section{Materials and Methods}

Raw material: Cottonseed (Gossypium spp.) variety MCU 5 was procured from the Department of Cotton, Tamil Nadu Agricultural University, Coimbatore. Enzymes like protease from Aspergillus oryzae, cellulase from Aspergillus niger, a-amylase from Aspergillus subtilis and USP grade gossypol standard were purchased from SigmaAldrich, USA.

Extraction of cottonseed milk: $100 \mathrm{~g}$ of cottonseed was soaked in $600 \mathrm{ml}$ of water for $90 \mathrm{~min}$ at $32^{\circ} \mathrm{C}$. Soaked cottonseeds were blended for $90 \mathrm{sec}$ in a blender. Cottonseed slurry samples were separately treated with $1 \%$ protease, cellulase and a-amylase enzyme at $\mathrm{pH} 7.0$ incubation of $40^{\circ} \mathrm{C}$ and $52^{\circ} \mathrm{C}$ and hydrolysis time of $2.30 \mathrm{hr}$ for the entire enzyme treated slurry samples. After hydrolysis, the slurry was filtered through a muslin cloth and the enzymes were inactivated at $90^{\circ} \mathrm{C}$ for 5 min and the cottonseed milk was packed in $250 \mathrm{ml}$ flask and stored at $4^{\circ} \mathrm{C}$ for further analysis. The conventional cottonseed milk extraction process was also carried out by following the same procedure at $30 \pm 2^{\circ} \mathrm{C}$ without adding of enzymes and served as control sample (Kumar, 2019).

Extraction yield: The percentage of cottonseed milk yield by enzyme treated and conventional (non-enzymatic) extraction 
process was calculated by the equation given below (Varghese and Pare, 2019).

$$
\text { Extraction yield }(\%)=\frac{W_{1}}{W_{2}} \times 100
$$

Where, $W_{1}$ is the cottonseed milk and $W_{2}$ is the cottonseed milk slurry.

Sedimentation percentage: Sedimentation percentage was measured by weighing the solids after removing the liquid through centrifuging at 2500 rpm for 10 min (Kabašinskienè et al., 2015). It was calculated by the following equation:

$$
\text { Sedimentation }(\%)=\frac{W_{1}}{W_{2}} \times 100
$$

Where, $W_{1}$ represents solids and $W_{2}$ cottonseed milk.

Protein estimation: Protein content was estimated by the Kjeldahl method from the crude nitrogen content and using the conversion factor of Nitrogen $\times 6.25$ to arrive at crude protein content (AOAC, 2019).

Gossypol estimation: The gossypol content of samples was determined by spectrophotometer with slight modification (Sadasivam and Manickam, 2005). A $0.5 \mathrm{ml}$ of phloroglucinol reagent and $1 \mathrm{ml}$ of concentrate hydrochloric acid was added to $0.1 \mathrm{ml}$ of cottonseed milk. It was incubated at room temperature for 30 min with 5 min of occasional shaking condition and made up to $10 \mathrm{ml}$ using $80 \%$ ethanol and vortexed for $10 \mathrm{sec}$. The solution and aliquots of different concentration of gossypol standard viz., $20,40,60,80$ and $100 \mu g ~ m l^{-1}$ were read at $550 \mathrm{~nm}$ absorbance in UV-Vis double beam spectrophotometer. A calibration curve was plotted between gossypol concentration and absorbance.

Statistical analysis: Statistical analysis was performed by SPSS 17.0 software for One way analysis of variance. The results are based on the mean value of three analytical values and SD. The significance of difference $(p<0.05)$ was evaluated by the influence of different enzymes and the extraction conditions of cottonseed milk.

\section{Results and Discussion}

The physico-chemical characteristics such as extraction yield, sedimentation percentage, protein and gossypol content were assessed in the extracted cottonseed milk treated with different enzymes and incubation conditions. The effect of enzymes and incubation conditions on the extraction of cottonseed milk are presented in Fig. 1. The results indicated that protease and a-amylase enzymes at 40 and $52^{\circ} \mathrm{C}$ resulted in maximum milk yield of 86.71 and $88.80 \%$ as compared with protease enzyme at $52^{\circ} \mathrm{C}(79.04 \%)$, cellulase enzyme at 40 and $52^{\circ} \mathrm{C}(75.09$ and $80.32 \%)$ and a-amylase enzyme at $40^{\circ} \mathrm{C}$ (84.29\%) compared to the control sample milk yield as $88.21 \%$, which was par with protease $\left(40^{\circ} \mathrm{C}\right)$, a-amylase $\left(52^{\circ} \mathrm{C}\right.$ and $\left.40^{\circ} \mathrm{C}\right)$ treated samples. The effect of enzymes and its incubation temperature on sedimentation percentage on cottonseed milk extract is presented in Fig. 2. The results revealed higher sedimentation percentage in a-amylase treated samples viz., 18.54 and $19.26 \%$ at incubation temperatures of 40 and $52^{\circ} \mathrm{C}$. Comparatively, less sedimentation percentage was observed in control $(2.54 \%)$ followed by protease enzyme treated samples $(3.72 \%)$ at $40^{\circ} \mathrm{C}$ and $3.52 \%$ at $52^{\circ} \mathrm{C}$ incubation temperature and cellulase enzyme treated samples on $6.04 \%$ at $40^{\circ} \mathrm{C}$ and $7.32 \%$ at $52^{\circ} \mathrm{C}$ incubation of the extracted cottonseed milk.

It was found that the concentration of a-amylase enzyme and incubation conditions were more effective in starch breakdown and hindered the protein matrix, which disturbed cell wall integrity and enabled to increase the extractability of sugars in plant sources (Gebremariam et al., 2013). The starch molecules tend to sediment quickly due to gravitation, and higher molecular size than protein molecules (Bertoft, 2017). Carbohydrase enzymes confer improved digestibility by breakdown of cellulose, hemicellulose and pectin fractions of cells to small oligomers and monomers (Marsman, 1997). The protein and gossypol content of extracted cottonseed milk as influenced by the application of different enzymes and incubation conditions compared to non-enzymatically treated control samples are presented in Table 1. Among the different samples, the protease enzyme treated samples at the incubation condition of 40 and $52^{\circ} \mathrm{C}$ showed significantly higher

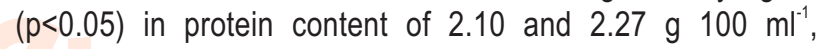
respectively compared to highest protein in control $(2.40 \mathrm{~g} 100$ $\left.\mathrm{ml}^{-1}\right)$ and lowest in a-amylase at $52^{\circ} \mathrm{C}$ treated sample $(1.18 \mathrm{~g}$ $100 \mathrm{ml}^{-1}$ ).

The cellulase enzyme treated samples at 40 and $52^{\circ} \mathrm{C}$

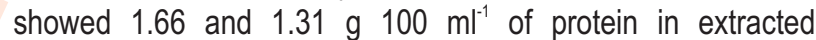
cottonseed milk. Proteolysis increases the protein solubility as well as reduces the anti-nutritional factors due to reaction of protease and also has positive effects on the extraction of protein and oil yield by the combined usage of cellulase and protease

Table 1: Effect of enzymes on chemical characteristics of extracted cottonseed milk

\begin{tabular}{llll}
\hline & \multicolumn{2}{c}{ Chemical characteristics } \\
\cline { 3 - 4 } Treatments & & $\begin{array}{l}\text { Protein } \\
\left(\mathrm{g} 100 \mathrm{ml}^{-1}\right)\end{array}$ & $\begin{array}{l}\text { Gossypol } \\
\left(\mathrm{mg} \mathrm{100} \mathrm{m}^{-1}\right)\end{array}$ \\
\hline Control & & $2.40 \pm 0.10^{\mathrm{a}}$ & $15.56 \pm 0.38^{\mathrm{e}}$ \\
Protease & $40^{\circ} \mathrm{C}$ & $2.10 \pm 0.01^{\mathrm{C}}$ & $9.28 \pm 0.38^{\mathrm{a}}$ \\
& $52^{\circ} \mathrm{C}$ & $2.27 \pm 0.02^{\mathrm{b}}$ & $10.08 \pm 0.44^{\mathrm{b}}$ \\
Cellulase & $40^{\circ} \mathrm{C}$ & $1.66 \pm 0.02^{\mathrm{d}}$ & $11.36 \pm 0.05^{\mathrm{c}}$ \\
& $52^{\circ} \mathrm{C}$ & $1.31 \pm 0.05^{\mathrm{e}}$ & $12.52 \pm 0.35^{\mathrm{d}}$ \\
a-amylase & $40^{\circ} \mathrm{C}$ & $1.35 \pm 0.01^{\mathrm{e}}$ & $14.88 \pm 0.52^{\mathrm{e}}$ \\
& $52^{\circ} \mathrm{C}$ & $1.18 \pm 0.03^{\dagger}$ & $15.24 \pm 0.54^{\mathrm{e}}$ \\
\hline
\end{tabular}

Each value mentioned as Mean $\pm S D$ of three replicate analysis $(n=3)$. The values mentioned in superscripts are significantly differed at $p<0.05$ in the same column 


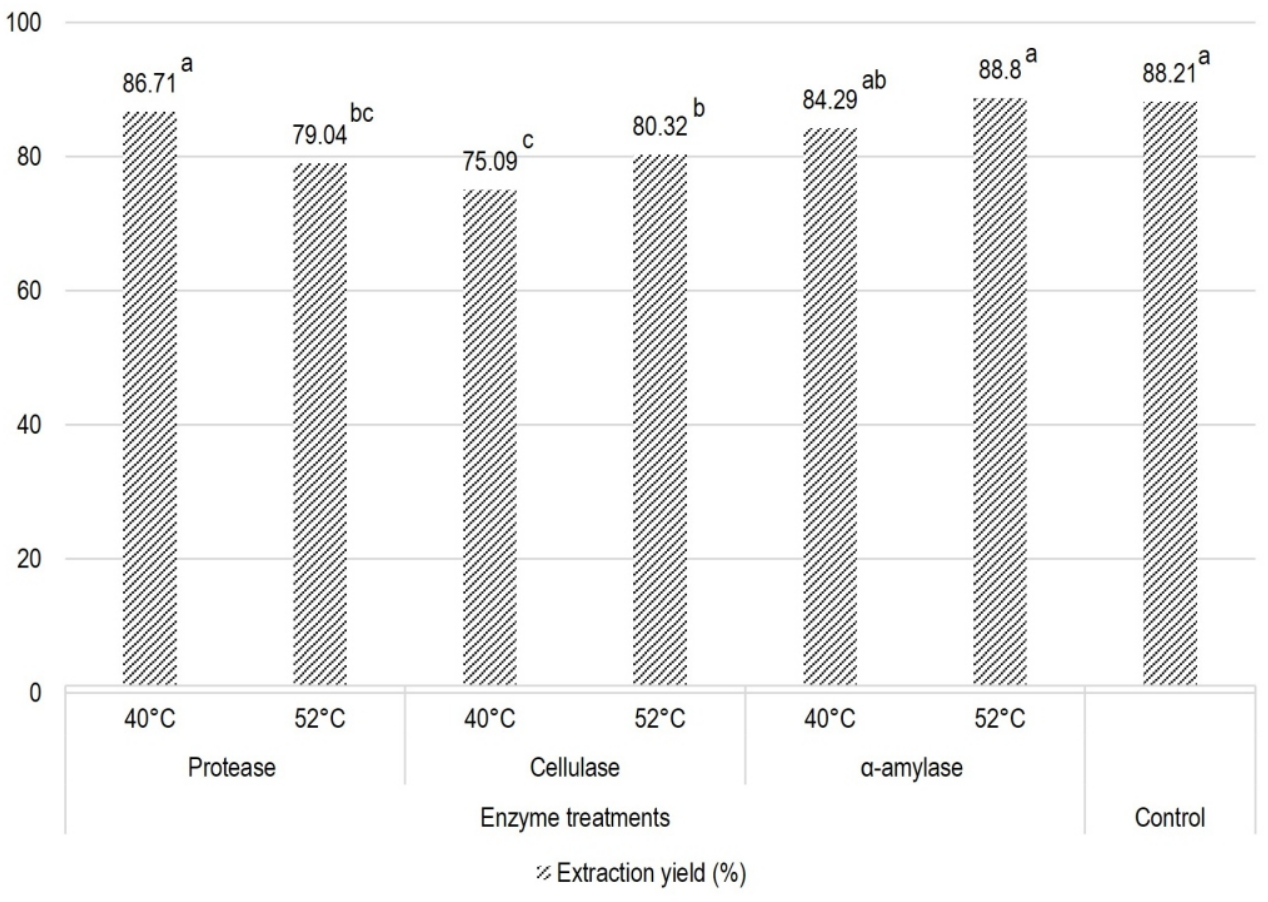

Fig. 1: Effect of enzymes in extracted cottonseed milk yield. Values are mean of three replicate $\pm S$.D. The values mentioned in superscripts are significantly differed at $p<0.05$ in the same row.

25

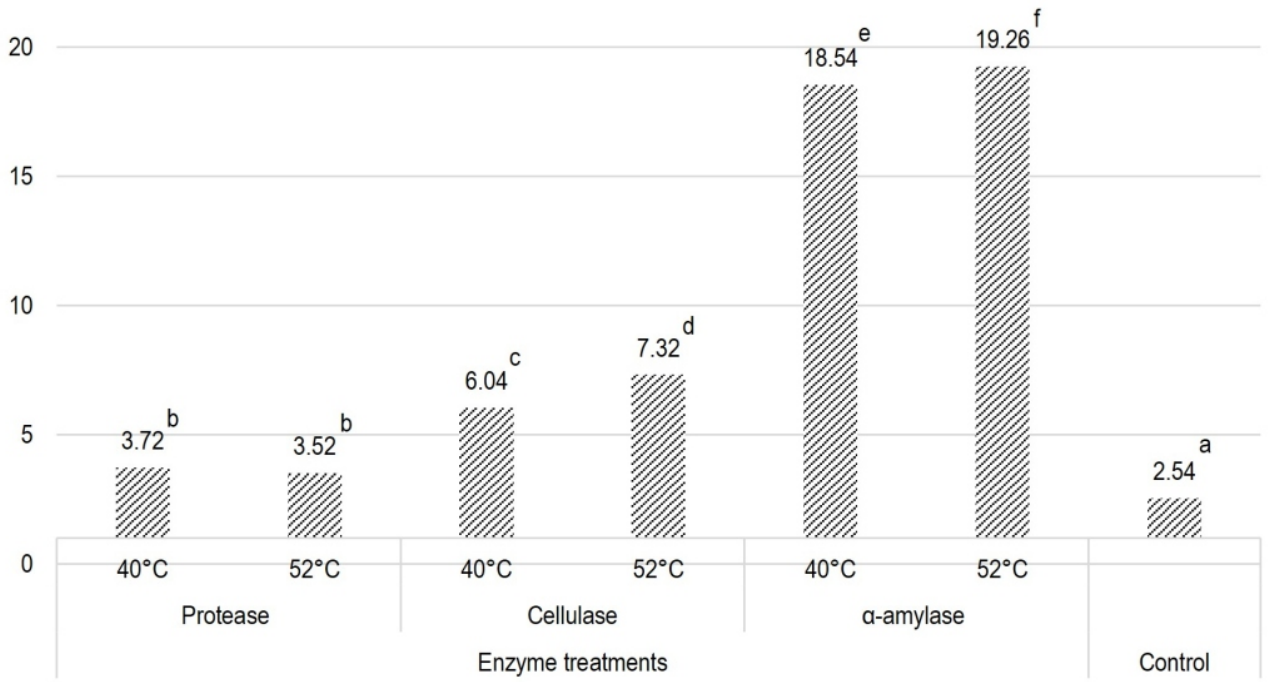

". Sedimentation (\%)

Fig. 2: Effect of enzymes on the sedimentation percentage of extracted cottonseed milk. Values are mean of three replicate $\pm S$.D. The values mentioned in superscripts are significantly differed at $p<0.05$ in the same row. 
enzymes under aqueous and solvent extraction conditions (Rosenthal et al., 2001). The relative activity of protease enzyme was 100,88 and $75 \%$ at 40,50 and $60^{\circ} \mathrm{C}$ and was also highly active at $\mathrm{pH} 7.0-9.0$ at $40^{\circ} \mathrm{C}$ in casein hydrolysis (Tang et al., 2010). The presence of protein and oil components in the cell wall suggests that easy release of more protein and oil molecules from the cellular matrix by protein degradation, was achieved by the action of protease enzyme (Passos et al., 2009). Single or combined treatment of protease neutrase and cellulase energex enhanced the protein extractability in soybean meals (Marsman, 1997). Similar findings on protein extractability was observed in extracted cottonseed milk by using protease and cellulase enzymes. The gossypol content of extracted milk was maximum

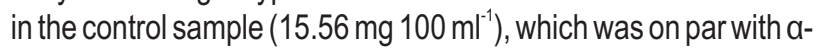
amylase treated samples followed by cellulase treated samples at both incubation temperatures. However, the samples treated with protease enzyme at 40 and $52^{\circ} \mathrm{C}$ showed $40.36 \%$ and $35.22 \%$ reduction in gossypol content and exhibited highly significant difference in the control sample.

The plausible reason being that free gossypol renders to modifying the pattern of amino acids released by enzymatic hydrolysis in both structural and functional protein, which results in molecular aggregation and solubility loss of proteins. Chen et al. (2019) reported that the total and free gossypol content decreased in the cottonseed meal by adding $2.5 \mathrm{ml}$ of enzyme from Helicoverba armigera CYP9A12, at hydrolysis condition of $35^{\circ} \mathrm{C}$ for $2.5 \mathrm{hr}$. Whatever, be the selection of cottonseed varieties and hydrolysis condition, such as the concentration of enzymes, $\mathrm{pH}$, time, temperature and microbial sources of enzymes, several factors influence the physico-chemical characteristics of extracted cottonseed milk and its derived products. At room temperature in the exposure of the cottonseed aqueous slurry to prolonged hydrolysis time may be contributing to the growing microbes in the end product.

Both enzymatically treated samples (protease, cellulase and a-amylase) and control samples in addition to the incubation condition resulted in the effective extraction yield, protein and gossypol content of cottonseed milk from the cottonseed with water as the extraction medium. Among the different treatments, cottonseed milk extracted with protease enzyme at $40^{\circ} \mathrm{C}$ and $52^{\circ} \mathrm{C}$ showed lower sedimentation and reduced gossypol content with a good amount of protein content and also notable amount of extraction yield. The extracted cottonseed milk meets the permissible intake level of gossypol content as regulated by the USFDA and FAO/WHO. It can be inferred that the cottonseed milk based derived products are more stable than animal based milk products, hence, the lactose free, high protein, low gossypol cottonseed milk may be a suitable alternative for lactose intolerant individuals.

\section{Acknowledgments}

Thirukkumar would like to thank the University Grant Commission (UGC), Government of India for the support of UGC-
NET-JRF for doctorate study.

\section{Add-on Information}

Authors' contribution: S. Thirukkumar: Carrying this reaserch and preparation of manuscript; G. Hemalatha: Providing Food Science lab facility; S. Vellaikumar: Providing Biotechnology lab facility; M. Murugan: Suggested for statistical analysis; S. Amutha: Guided for manuscript preparation.

Research content: The research content of manuscript is original and has not been published elsewhere.

Ethical approval: NotApplicable

Conflict of interest: The authors declare that there is no conflict of interest.

\section{Data from other sources: NotApplicable}

Consent to publish: All authors agree to publish the paper in Journal of Environmental Biology.

\section{References}

AOAC: Official Methods of Analysis. $21^{\text {st }}$ Edn., Rockville, Maryland, US (2019).

Bertoft, E.: Understanding starch structure: Recent progress. Agronomy, 7,56 (2017).

Bertrand, J.A., T.Q. Sudduth, A. Condon, T.C. Jenkins and M.C. Calhoun: Nutrient content of whole cottonseed. J. Dairy Sci., 88, 1470-1477 (2005).

Cao, H., K. Sethumadhavan and J.M. Bland: Isolation of cottonseed extracts that affect human cancer cell growth. Sci. Rep., 8, 1-12 (2018)

Chen, C., Y. Zhang, W. Pi, W. Yang, C. Nie, J. Liang and W.J. Zhang: Optimization of the process parameters for reduction of gossypol levels in cottonseed meal by functional recombinant NADPHcytochrome P450 reductase and cytochrome P450 CYP9A12 of Helicoverpa armigera. AMB Expre., 9, 1-10 (2019).

Das, A., U. Raychaudhuri and R. Chakraborty: Cereal based functional food of Indian subcontinent: A review. J. Food Sci. Technol., 49, 665-672 (2012).

Gadelha, I.C.N., N.B.S. Fonseca, S.C.S. Oloris, M.M. Melo and B. SotoBlanco: Gossypol toxicity from cottonseed products. Sci. World J., 2014, 1-6 (2014)

Gebremariam, M.M., M. Zarnkow and T. Becker: Thermal stability of starch degrading enzymes of teff (Eragrostis tef) malt during isothermal mashing. Process Biochem., 48, 1928-1932 (2013).

Jasielska, M. and U. Grzybowska-Chlebowczyk: Lactose malabsorption and lactose intolerance in children with inflammatory bowel diseases. Gastroenterol. Res. Pract., 2019, 1-6 (2019).

Kabašinskienè, A., A. Liutkevičius, D. Sekmokienè, G. Zaborskienè and J. Šlapkauskaitè: Evaluation of the physico-chemical parameters of functional whey beverages. Food Technol. Biotechnol., 53, 110115(2015).

Kirk, O., T.V. Borchert and C.C. Fuglsang: Industrial enzyme applications. Curr. Opin. Biotechnol., 13, 345-351 (2002).

Kumar, M.: Paruthi Paal, a nutrient-rich healthy drink from cottonseed: An Indian delicacy. J. Ethn. Foods, 6, 1-6 (2019). 
Marsman, G.J.P., H. Gruppen, A.J. Mul and A.G.J. Voragen: In-vitro accessibility of untreated, toasted, and extruded soybean meals for proteases and carbohydrases. J. Agric. Food Chem., 45, 40884095 (1997).

Passos, C.P., S. Yilmaz, C.M. Silva and M.A. Coimbra: Enhancement of grape seed oil extraction using a cell wall degrading enzyme cocktail. Food Chem., 115, 48-53 (2009).

Prasad, R. and D. Blaise: Low gossypol containing cottonseed: Not only a fibre butalso a food crop. Natl. Acad. Sci. Lett., 43, 599-602 (2020).

Rosenthal, A., D.L. Pyle, K. Niranjan, S. Gilmour and L. Trinca: Combined effect of operational variables and enzyme activity on aqueous enzymatic extraction of oil and protein from soybean. Enzyme Microb. Technol., 28, 499-509 (2001).

Sadasivam, S. and A. Manickam: Biochemical Methods. $2^{\text {nd }}$ Edn., New Age International (P) Ltd, Publishers, New Delhi, India (2005).

Santana, A.T., M. Guelfi, H.C. Medeiros, M.A. Tavares, P.F. Bizerra and F.E. Mingatto: Mechanisms involved in reproductive damage caused by gossypol in rats and protective effects of vitamin E. Biol. Res., 48, 1-8(2015).

Sethi, S., S.K. Tyagi and R.K. Anurag: Plant-based milk alternatives an emerging segment of functional beverages: A review. J. Food Sci. Technol., 53, 3408-3423 (2016).

Tang, C., Q. Meng, K. Zhang, T. Zhan, Q. Zhao, S. Zhang and J. Zhang:
Multi-omics analyses of red blood cell reveal antioxidation mechanisms associated with hemolytic toxicity of gossypol. Oncotarget, 8, 103693 (2017).

Tang, X.Y., B. Wu, H.J. Ying and B.F. He: Biochemical properties and potential applications of a solvent-stable protease from the highyield protease producer Pseudomonas aeruginosa PT121. Appl. Biochem., 160, 1017-1031 (2010).

Varghese, T. and A. Pare: Effect of microwave assisted extraction on yield and protein characteristics of soymilk. J. Food Eng., 262, 9299 (2019).

Wang, K.Z., L. Feng, W.D. Jiang, P. Wu, Y. Liu, J. Jiang and X.Q. Zhou: Dietary gossypol reduced intestinal immunity and aggravated inflammation in on-growing grass carp (Ctenopharyngodon idella). Fish Shellfish Immunol., 86, 814-831 (2019).

Xiong, J., J. Li, Q. Yang, J. Wang, T. Su and S. Zhou: Gossypol has anticancer effects by dual-targeting MDM2 and VEGF in human breast cancer. Breast Cancer Res., 19, 1-10 (2017).

Yu, Q., Z. Hu, Y. Shen, Y. Jiang, P. Pan, T. Hou and Y. Sun: Gossypol inhibits cullin neddylation by targeting SAG-CUL5 and RBX1CUL1 complexes. Neoplasia, 22, 179-191 (2020).

Zhang, L., S. Sun, Y. Wang, Y. Mo, F. Xiong, S. Zhang and C. Guo: Gossypol induces apoptosis of multiple myeloma cells through the JUN-JNK pathway. Am. J. CancerRes., 10, 870 (2020). 